\section{Ethical Lingua}

Journal of Language Teaching and Literature

ISSN 2355-3448 (Print)

ISSN 2540-9190 (Online)

Volume 6, Number 2, August 2019

pp. $59-71$

\title{
Tackling Difficulties in Translating Culture-bound Metaphor in Nizar Qabbani's Poetry: A Comparative Study
}

\author{
Loubna Haddi \\ loubnahaddi@yahoo.co.uk \\ Hassan II University, Morocco \\ Received : 25 July 2019; Accepted: 29 August 2019 \\ $\mathrm{DOI}$ \\ : https://doi.org/10.30605/25409190.v6.59-71
}

\begin{abstract}
Arabic poetry has long taken precedence over other literary forms. It is the oldest form of literature known in the Arabic language, dating back to year 400 A.D. In the context of translation, poetry poses a few daunting hurdles in attempting to reach equally metaphorical meanings in the target language. This article seeks to illustrate the cultural problems witnessed in translating culture-bound metaphor. For this purpose, poetry by prominent Arab poet Nizar Qabbani is the main reference and the selected case study in the article for the poet's place and contribution in Arabic poetry. The theoretical framework adopts two translation models- Newmark's Semantic Translation and Den Broeck's literal, paraphrase and substitution. In addition to illustrating difficulties emanating from translating culture-bound metaphor, the article will present a comparative analysis of two translations of one poetic text, thereby hopefully serving as a valuable contribution to the area of cultural metaphor translation by providing a range of translation possibilities starting from Dynamic Equivalence or idiomatic translation and continuing through literal and semantic translations. In doing so, the article has tackled strategies in the field of cultural metaphor translation, which will hopefully lead to further research.
\end{abstract}

Keywords: translation, metaphor, Arabic poetry, Nizar Qabbani 
Haddi:

Tackling Difficulties in Translating Culture-bound Metaphor in Nizar Qabbani's Poetry

\section{Introduction}

The concept of translation is equivocal and can be tackled differently by various translation scholars. The key to defining translation lies in "establishing the boundaries of the translation text, which in semiotic analysis is one of the first procedural moves towards understanding something in its wholeness or as a whole" (Personen, Hellman Huttunen, Obatnin, 2007, p. 204). The concept can be viewed from a restrictive or a non-restrictive point of view. Bassnet-McGuire (1980) puts forward:

Translation involves the rendering of a source language $S L$ text into the target language $\mathrm{TL}$ so as to ensure that the surface meaning of the two will be approximately similar and the structures of the SL will be preserved as closely as possible but not so closely that the TL structures will be seriously distorted. (p. 2).

This definition appears to shed light on the strict rendering of meaning from SL to TL, with the meaning prioritized over the structures. Nida's (1964) less restricted view of translation, on the other hand, encompasses two ideas-formal and dynamic equivalences. In formal equivalence, it is posited that "translation is basically source-oriented; that is, it is designed to reveal as much as possible the form and content of the original message" (Nida, 1964, p. 134). In the case of dynamic equivalence, the focus is shifted towards the receptor response instead of the source message, given that what is of key importance is the rendering of $S L$ text into $T L$ text for a same response from both readers of the source and target languages. The dynamic equivalence is defined as "the closest natural equivalence to the source language message" (Nida, 1964, p. 166). These two translation strategies seem to focus on two different variables-focus on SL meanings and reception thereof in TL. The article embarks on the premise of whether the application of these concepts-formal equivalence and dynamic equivalence-to poetry is possible and attempts to shed light on the daunting challenges translators go through in translation.

Overcoming the cultural boundaries involves conveying the overarching message and effect aspired by the poet. This requires thorough knowledge of SL and TL languages and their associated cultures as well as guidance by the theories on cultural untranslatability.

Poetry is characterized by the presence of rhyme and meter and poetic devices such as assonance, alliteration, etc. and by the use of figures of speech such as metonymy, synecdoche, and metaphor. One of the reasons behind the use of metaphor in poetry is that it involves lexical deviation-a stylistic figure that poets enjoy as compensation for the rigid poetical rules. Additionally, metaphors used in poetry are more of a specific reflection of the poet's cultural heritage. This article aims at recognizing the essential relation between culture and metaphor and seeks to tackle the problem of translating cultural metaphor in 
poetry. Arab poet Nizar Qabbani's poem titled Bread, Hashish, and the moon is used as a case study.

\section{Theory of Translation}

Translation theory draws upon a number of studies intended to provide translators with methods, strategies, and principles, which help achieve substantial results. Newmark (1981) states that "translation theory's main concern is to determine appropriate translation methods for the widest range of text or text categories" (p. 19). It appears that translation theory is text-oriented theory. Although mainly hybrid, texts are most commonly categorized into expository, argumentative, and instructive (Hatim and Mason, 1990).

Literary translation is treated within the framework of a text, according to Holmes (1988), who notes that literary translation is solely a question not of translating a series of sentences but of translating text. In some typologies, poetic texts are grouped within literary texts and in others they stand separately as texts. There are several approaches to the translation of poetry, whether on the text level or on lower levels-e.g. words, sentences, lines, etc.

\section{Definition of Metaphor}

There has been little consensus regarding the definition of metaphor in current dictionaries. The Longman Modern English Dictionary (2019) defines metaphor as "the use of a phrase which describes one thing by stating another thing with which it can be compared without using the words (as) or (like)"-e.g. the roses in her cheeks (p. 528). The Collins English Dictionary and thesaurus (1993) define metaphor as "a figure of speech in which a word or a phrase is applied to an object or an action that it does not literally denote in order to imply resemblance"-e.g. he is a lion in battle (p. 717).

However, these definitions lack comprehensive insight into how to recognize and understand metaphor in use. Kittay (1987) suggests that "language can only be identified as metaphorical by virtue of contextual conditions that require that we interpret it differently from its surrounding discourse" (p. 40). Therefore, the utterance or sentence level may not be adequate to understand a metaphorical expression.

\section{Translation of Poetry}

In light of what has been referred to earlier, Holmes (1988) provides a riveting intake towards poetic translation, in which he suggests that texts are both serial and structural. He states that translating texts occurs on two planes: a serial plane where one translates sentence by sentence and a structural plane:

....after one has read a text in time, one retains an array of data about it in an instantaneous form. On these grounds, it has more recently been suggested (though nowhere, as far as I know, clearly set out in model form) that the translation of texts (or at least of extensive 
Haddi:

Tackling Difficulties in Translating Culture-bound Metaphor in Nizar Qabbani's Poetry

texts, or at least of complex texts) takes place on two planes: a serial plane, where one translates sentence by sentence, and a structural plane, on which one abstracts a 'mental conception' of the original text, then uses that mental conception as a kind of general criterion against which to test each sentence during the formulation of the new, translated text (Holmes, 1988, p. 82).

This model consists of two planes and two maps. It is worth noting that a number of rules interfere in the whole process: 1) Derivation rules (DR), which determine the abstract of the first map from the ST; 2) Equivalence rule (ER), which determine the development of the target text map from the ST map and finally, 3) Projection rules, which interfere in the shaping of the prospective TT.

Holmes (1988) points out that the ST map would normally be a "conglomerate of highly separate bits of information" (p. 84); first as a map of linguistic artifact (Contextual information), secondly, literary artifact (inter-textual information), and thirdly, a socio-cultural artifact (situation information). Holmes moves on to the problems confronting the translator of poetic texts, wherein these problems fall in two areas, namely form and function, around which his argument revolves. He maintains that for every feature in the ST map there are at least two correspondences available in the TT map. One of these correspondences may correspond in form but not in function while the other may correspond in function but not in form. There are also features that correspond in meaning but neither function nor form. The author believes that translators opt for form rather than function when they deal with social-cultural problems while they opt for function rather than form when they deal with linguistic problems. Holmes (1988), however, argues that translators "seem to exercise a great deal of freedom of choice as regards the various features of poetic form" (p. 85). Additionally, he draws our attention to the "...interdependence among correspondence in connection with one feature of the source-text map determines the kind of correspondence available for another or others..." (Holmes, 1988, p. 86).

\section{Semantic Translation: (Newmark's model)}

Newmark (1988) puts forth the notion that semantic translation may often be an effective way of bringing across the 'flavor' of a text. This method is applied when an adequate semantic and 'cultural functional terms' of the SL text can be obtained in the TL with slight adjustments on the part of the translator. The readers will realize that they are reading a translation rather than the original text, but this will add to the interest of the piece. An example of semantic translation was introduced in the 3rd chapter:

$$
\text { و أحز اني عصافير تفتش بعد عن بيدر }
$$

Literal translation:

And my grieves are ...sparrows still looking for a threshing-floor 
Semantic translation:

And my grieves are sparrows looking for a place to roost

The choice for the word roost instead of the literal translation threshing-floor occurred because, 1) it fulfills the intended function of the SL text, 2) from a lexical standpoint, it is more poetic and sounds natural to utter a place to roost, 3 ) it is an adequate cultural equivalent for the original item.

\section{Paraphrase (Free Translation)}

When the literal or semantic rendering of the SL text cannot be comprehended by the TL reader and no cultural equivalent exists in the TL, the translator is then forced to paraphrase in the SL text. However, this method fails to convey the effect to the original text as it involves explanations that spoil the poetic impact of both the semantic and stylistic features. The cultural aspects of texts in general and literary (poetic) texts in particular are dynamic and vital for the communicative values of the text. Thus, the receptor's response must be taken into consideration when the translator decides on their translation technique. Nida (1964) maintains that "the conformance of a translation to the receptor language and culture as a whole is an essential ingredient in any stylistically acceptable rendering" (p. 167). Faithfulness to the original cultural message remains another challenging criterion the translator has to test their work against.

\section{The Translation of Metaphor}

In translation, the translator plays the crucial role of "a mediator not only between languages but also between cultures has been shown, and these studies have concluded that the translation of metaphor is mainly influenced by conceptual cultural similarities and/o differences" (Musolf, MacArthur, Pagani, 2014 , p. 74). Several translation scholars have investigated the problems of translating metaphor (Newmark, 1981; Dagut 1976; Den Broeck, 1981). Metaphor translation schools have taken into account the cultural associations of metaphor and how culture may affect its movement from one language to another. Dagut (1976) notes that metaphors are predominantly cultural and hence the problem is insoluble unless the language in question is culturally related.

Before examining some various approaches to the translation of metaphor in general and the culture-bound metaphor in particular, I would like to mention types of metaphor, live metaphor and dead metaphor. Larson (1984) identifies both types:

Dead metaphors are those which are a part of the idiomatic construction of the lexicon of the language. Live metaphors on the other hand, are those which are constructed on the spot by the author or speaker to teach or illustrate. ( $p$. 249) 
Haddi:

Tackling Difficulties in Translating Culture-bound Metaphor in Nizar Qabbani's Poetry

Dead metaphors do not pose a problem in translation as they can be translated directly into the TL like the rest of non-figurative language. Translation of live metaphors is the subject of study and investigation as it is not always possible to relay the figurative content of these metaphors. Larson (1984) summarizes the difficulties of translating metaphor in the following way:

1. The image used in the metaphor may be unknown in the receptor language.

2. The topic (Newmark's object) may not be clearly stated and hence pose a problem for the readers.

3. The point of similarity could be implicit and hard to identify. The author asserts: "one of the more serious problems is the fact that the point of similarity may be understood differently in one culture than another" (Larson, 1984, p. 251).

4. The receptor language does not make comparisons of the type that occurs in the source text metaphor.

However, translation studies are not limited to merely stating the problem. Translation scholars have introduced several strategies to limit the translation difficulties of metaphorical expressions.

\section{Den Broeck (1981)}

Den Broeck (1981) sheds light on other aspects of metaphor translation. He notes that some outlines should be made of how "metaphors are to be translated in order that optimal correspondence between SL text and TL text may be established" (p. 77). The writer later reveals that such generalizations can hardly be attained and hence he suggests three "possibilities" of translating metaphor.

1. Literal translating: a metaphor is translated literally when both the SL topic and image are rendered into the TL.

2. Substitution: a metaphor is substituted for another when the SL image is replaced by TL image.

3. "Paraphrase: a metaphor is paraphrased whenever it is rendered by a non-metaphorical expression in the TL" (Den Broeck, 1981, p. 77).

Despite the solutions the writer has introduced, Den Broeck (1981) defines three areas where the translation of metaphor can be seriously hindered:

1. "when a poetic metaphor is based on a grammatical peculiarity of the SL" (p. 80).

2. "...the extra linguistic factor in metaphors, the so-called cultural context in which they originate" (p. 80) may cause immense difficulties.

3. The third problem resides in the differences in "aesthetic convention and tradition" (p. 81) Den Broeck continues to illustrate "translatability will thus be high in the case of shared literary traditions or at least depend on the availability in the target literary system of similar symbolical traditions which can provide adequate substitutes" (p. 81) 
Again, the cultural element in the formation of metaphor stands as a major difficulty in metaphor translation. It is noticed that it is a recurring subject in any theoretical or empirical study of metaphor. There is a consensus among translation scholars that the closer the cultural overlap in metaphor translation the less problematic the translation. Consequently, in the case of Arabic and English, the problem is more pressing.

\section{Translation of Culture-Bound Metaphor}

When the metaphor is culture-bound, the translator should consider the difficulties of translating metaphors and translating cultural entities. Cultural features are terms, words, or cultural presuppositions-social, religious, etc. In the case of poet Nizar Qabbani, the metaphors employed are predominantly original. Although Newmark (1981) states that original metaphors do not embody many cultural features, Nizar Qabbani defies this rule as his metaphors are original. In the course of the translations, literal translation will unfold as a dominant strategy unless inappropriate, then other techniques will be adopted. Literal rendering of metaphor, when possible, discloses both the writer and the reader who is inclined to interpret it subjectively and according to personal preferences. Therefore, keeping the metaphor preserves its multi-dimensional features. Otherwise, the translator is forced to apply componential analysis in order to reproduce the most appropriate point of similarity-sense.

\section{Method}

This article presents a comparative analysis of two translations of a few verses of 'bread, hashish, and the moon'. The first translation is my proposed version; the second is collected from the anthology of modern Arabic poetry (1974). The article attempts to analyze how culture-bound metaphors are translated and whether they are rendered literally or semantically, which discloses the translator's preference.

\section{Results}

\section{Proposed Translation}

Bread, hashish, and the moon

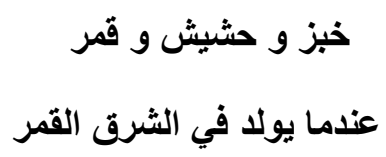

(1) in the orient when the moon is born

(2) white rooftops drift into sleep

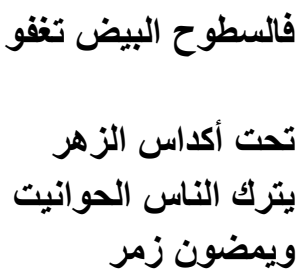

(3) under mounds of flowers people leave their shops and walk in groups 
Haddi:

Tackling Difficulties in Translating Culture-bound Metaphor in Nizar Qabbani's Poetry

(4) to meet the moon

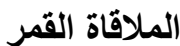

they carry bread, gramophones

يحملون الخبز و الحاكي

(5) and other means of getting high

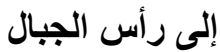

ومعدات الخدر

(6) they buy and sell illusions

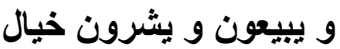

and images

وصور

what does that luminous disk

ما الذي يفعله قرص ضياء

do to my country

the country of prophets

the country of the simple

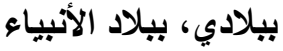

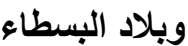

(7) and they shake the tombs of saints

و يهزون قبور الأولياء

begging them for rice and children

علها ترزقهم رزاو او أطفالا

they spread out elegant carpets

قبور الأولياء

(8) they console themselves with an opium

called fate and destiny

in my country

the country of the simple

and they call on the crescent

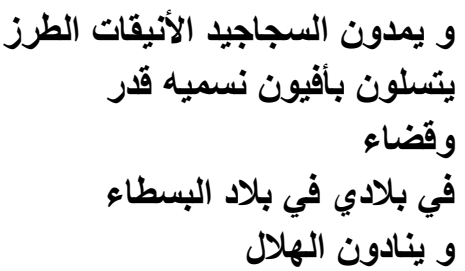

(9) oh crescent, oh that spring

which showers diamonds

hashish and drowsiness

أيها النبع الذي يمطر ماس

و حثيشا و نعاس الت بمط

(10) oh that god of marble

oh that incredible being

long may it live for the orient

أيها الرب الرخامي المعق

أيها الثيء الثي الذي ليس يصدق الئق

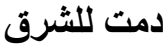

for us

لنا

(11) a cluster of diamonds

for the millions who

عنقود ماس

switched off their senses

in my country where the stupid cry

and die crying

whenever the crescent appears

and their crying increase

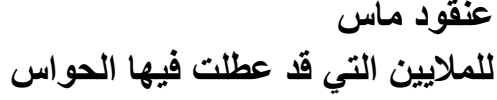

في بلادي حيث يبكي الأغبياء

و يموتون بكاء

كلما طالعهم وجه الهيلال

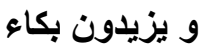

(12) whenever they are moved

كلما حركهم عود دليل...وليل

by a wretched lute

in my country

في بلادي، في بلاد البسطاء 
the country of the simple

(13) where we recycle endless lyrics, history

lethargic dreams

and fairy tales

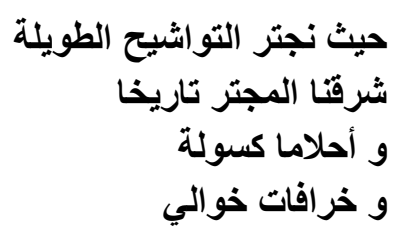

أشرقنا الباحث عن كل بطوله

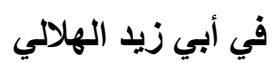

\section{Khouri \& Algar's (1974) Translation}

(1) when the moon is born in the east

(2) and white rooftops drift asleep

(3) under the heaped up light

people leave their shops and march forth in groups

(4) to meet the moon

carrying bread, and a radio, to the mountain tops

(5) and their narcotics

(6) there they buy and sell fantasies

and images

what does that luminous disk

do to my land

the land of the prophets

the land of the simple.

(7) and shake the tombs of the saints

hoping to be granted some rice, some children

they spread out their fine elegant rugs

(8) and console themselves with an opium we call fate and destiny

in my land, the land of the simple

calling on the crescent moon

oh crescent moon...

(9) oh...spring raining forth diamonds.

hashish and apathy!

(10) oh suspended god of marble

oh unbelievable object

always you have been for the east, for us

(11) a cluster of diamonds

for the millions whose senses are numbed

in my land

\footnotetext{
${ }^{1}$ A legendary character of (A Thousand and One Nights) who does heroic deeds that transcend the conceivable and rational.
} 
Haddi:

Tackling Difficulties in Translating Culture-bound Metaphor in Nizar Qabbani's Poetry

where the stupid weep

and die weeping

whenever the crescent moon appears

and their tears increase

(12) whenever some wretched lute moves them...or the song

"tonight"

(13) where we slowly chew on our unending songs

our east chewing on its history

its lethargic dreams,

its empty legends

(14) our east that sees the sum of all heroism

in picaresque Abu Zaid al Hilali. (Khouri \& Algar, 1974, p. 175)

\section{Analysis of Translations}

This part provides analysis of the two translation versions of the poem, allowing insight into the translator's preferences and used words for culture-bound metaphors.

\section{Analysis of My Translation}

(1) In the orient when the moon is born

Literal translation, literal rendering of the original image.

(2) White roof tops drift into sleep

Literal rendering of the original image.

(3) Under mounds of flowers

To meet the moon

Literal rendering of the original image

(4) and other means of getting high

Reduction of the metaphor to its point of similarity.

(5) They buy and sell illusions and images

Literal rendering of the original image.

(6) And they shake the tombs of saints

Begging them for rice and children

Here I have kept the metaphor but I have embedded the Point of similarity by writing the word (begging), Thus in this case, we have the metaphor plus the Point of similarity. 
(7) They console themselves with an opium Called fate and destiny

The literal translating of (يتسلون) is (amuse themselves). By translating it as (console) half the metaphor is actually reduced to its point of similarity while the other half is rendered literally.

(8) Oh that god of marble

Oh that incredible being

Literal rendering of the image plus I have deleted the word (المعلق) (suspended) as it is not strictly necessary to understanding the text. It does not make the metaphor more ambiguous. At the same time the line sounds more poetic.

(9) Oh crescent, oh that spring

Which showers diamonds, hashish

And drowsiness

Literal rendering of the original image.

(10) A cluster of diamonds

Literal meaning of the original image.

(11) Whenever they are moved

By a wretched lute

Literal rendering of the first part of the metaphor and deletion of the other part (ليال) is a cultural word which indicates a types of song known in the Middle East (slow, repeated, long). There is obviously no equivalent for this type of singing in the TL culture. If the metaphor was rendered literally, it would be meaningless. I feel that the function of this metaphor has been fulfilled in other parts of the text (wretched lute, endless lyrics) and hence it can be deleted.

(12) Where we recycle endless lyrics, history lethargic dreams and fairy tales.

I hope that I have produced the image of the original metaphor. The method I have applied is semantic translation.

(13) Our orient which seeks heroism

In "Abu Zaid Al Hilali"

The metaphor is preserved as a corresponding footnote is needed.

\section{Analysis of Khouri \& Algar's (1974) Translation}

\section{$1 \& 2$ when the moon is born in the east. And white roof tops drift asleep}

Literal rendering of the original image. 
Haddi:

Tackling Difficulties in Translating Culture-bound Metaphor in Nizar Qabbani's Poetry

$3 \quad$ under the heaped-up light

Reduction of metaphor to its point of similarity.

4,5 \& 6 to meet the moon

And their narcotics

There they buy and sell fantasies

Literal rendering of the original image.

$7 \quad$ and shake the tombs of saints

Hoping to be granted some rice, some children.

Again it is a literal rendering of the original image.

8 and console themselves with an opium called fate and destiny.

This is the same translation that is used before and the comments can be applied here. (see earlier in the chapter).

$9,10 \& 11$ oh crescent moon!

oh that spring raining

oh suspended god of marble

oh unbelievable object

a cluster of diamonds

Literal rendering of the original message.

12 whenever some wretched lute moves them or the song "tonight".

Literal rendering of the original image, though I think that "the song tonight" is ambiguous, even a long explanation may not be adequate to convey the meaning or the effect. A deletion could be the appropriate technique which I adopted in the first translation.

13 here we slowly chew on our unending songs.

Literal rendering of the first part of the metaphor. (songs) is a neutral term (semantic translation) for the cultural term (ARABE). It may be associated by the reader with the (song tonight) but in fact they are different and the translator should take that into consideration.

14 our east that sees the sum of heroism

In picaresque Abu Zaid Al Hilali

The first line involves a paraphrase. The cultural metaphor in the second line is almost meaningless despite the addition of (picaresque) as it is more related to Spanish culture. The strategy here is a point of similarity and metaphor. 


\section{Conclusion}

This article has attempted to illustrate the cultural problems in translating metaphor. For this purpose, Nizar Qabbani's poetry was chosen, in particular, his poem titled Bread, Hashish, and The Moon. Theoretical contributions to the translation of cultural metaphors in poetry were referenced. Strategies and methods directly related to the field of this study were also discussed. The article subsequently presented a comparative analysis of the two translations of one poetic text, thereby serving as a contribution to the area of translating predominantly cultural metaphor. This is also an attempt to present a range of translation possibilities starting from dynamic equivalence or idiomatic translation and continuing through literal and semantic translations, wherein adjustments or neutral cultural words can solve the problem, then ended with paraphrase. The conclusion is characterized by with the idea that literal translation of cultural metaphor does not always hold possible; if the translator's inclination is more towards using this method, then supplementary information in the form of a footnote is indispensable. To conclude, this attempt has tackled the problem of translating cultural metaphor with specific strategies that may render it useful and which will lead to further research in this area.

\section{References}

Bassnett-McGuire, S. (1991). Translation studies. London: Routledge.

Dagut, M. (1976) Can metaphor be translated, Bable XII, 21-33.

Van den Broeck, R. (1981). The limits of translatability exemplified by metaphor translation. Poetics Today

Holmes, J. S (1988). Translated! Amsterdam editions. Rodopi B.V.

Kittay, E. F. (1987). Metaphor: Its cognitive force and linguistic structure. Oxford: Clarendon Press.

Khouri, M. A., \& Algar, H. (1975). An anthology of modern Arabic poetry. Berkeley: University of California Press.

Larson, M. L. (1984). A guidance to cross language equivalence. London University Press of America.

Newmark, P. (1981). Approaches to translation. Oxford: Pergamon Press.

Musolff, A., MacArthur, F., \& Pagani, G. (2014). Metaphor and Intercultural Communication. London.

Nida, E. A. (1964) Towards a science of translating. Leiden: E.J Brill.

Hatim, B., \& Mason, I. (1990). Discourse and the translator. London: Longman.

Pesonen, P., Hellman, B., Huttunen, T., \& Obatnin, G. V. (2007). Varietas et concordia: Essays in honour of Professor Pekka Pesonen on the occasion of his 60th birthday. Helsinki: Dept. of Slavonic and Baltic Languages and Literatures, University of Helsinki.

Tāj, -D. A. (2001). Nizār Qabbānī wa-al-shirr al-siyāsī. al-Qāhirah: al-Dār al-Thaqāfĩyah lil-Nashr. 